[Agr. Biol. Chem., Vol. 28, No. 11, p. 765 769, 1964]

\title{
Riboflavin Biosynthesis by Candida robusta
}

\author{
Part III. Effect of Metal Ion and Necessity of $\mathrm{CaCO}_{3}$
}

\author{
By Shoichi TAKaO \\ Laboralory of Applied Microbiology, Faculty of Agriculture, \\ Hokkaido University, Sapporo \\ Received May 13, 1964
}

\begin{abstract}
Metal ions had little influence on riboflavin production by Candida robusta, except that $\mathrm{Ag}$, $\mathrm{Cu}$ and Hg were strongly inhibitory. The inhibiting action of iron on its production was comparatively small, so that any previous treatment for the removal of iron from the medium was not necessary. Addition of $\mathrm{CaCO}_{3}$ was found to be essential. in media containing sucrose or acetate as a carbon source, as pointed out in the previous paper. ${ }^{17}$ This effect of $\mathrm{CaCO}_{3}$ was attributed to its neutralizing action. When the reaction of the medium was kept at the optimum $\mathrm{pH}$, about 7.0 , high yields of riboflavin could be obtained without the presence of $\mathrm{CaCO}_{3}$.
\end{abstract}

\section{INTRODUCTION}

In the previous papers, ${ }^{1,2)}$ it was reported that six strains of Candida robusta, isolated from fruits, had abilities to synthesize ribollavin in shaking culture, and acetate was much more effective as a carbon source than sugar. Amino acids, asparagine and peptone were unsuitable as nitrogen sources in the sucrose medium, but they were as effective as ammonium salts and urea in the acetate medium. No flavinogenic factor was necessary. However, the addition of excessive $\mathrm{CaCO}_{3}$ was essential for the riboflavin production.

In this paper, the effect of metal ions on riboflavin production is reported and necessity of $\mathrm{CaCO}_{3}$ is also explained.

\section{MATERIALS AND METHODS}

\section{Microorganisms.}

Candida robusta No. 6 , selected as the best strain with riboflavin-producing ability (refer to the previous paper ${ }^{2}$ ), was obtained from the Laboratory of Applied Microbiology, Hokkaido University.

Culture Procedure.

After growing on potato glucose agar slant at $30^{\circ} \mathrm{C}$ for

1) S. Takao, This Journal, 28,559 (1964).

2) S. Takao, ibid., 28, 566 (1964).
3 days, the yeast was inoculated into $50 \mathrm{ml}$ of the following medium containing Ca-acetate or sucrose, as a carbon source, in 500-ml shake flasks, then cultured on a shaker at $30^{\circ} \mathrm{C}: 0.3 \%\left(\mathrm{NH}_{4}\right)_{2} 5 \mathrm{O}_{4}, 0.2 \% \mathrm{KH}_{2} \mathrm{PO}_{4}, 0.1 \%$ $\mathrm{MgSO}_{4} \cdot 7 \mathrm{H}_{2} \mathrm{O}$ and $5 \% \mathrm{CaCO}_{3}$. Ten $\mathrm{ml}$ of the medium in shake tubes were also used in some additional experiments.

Analysis.

Riboflavin was estimated fuorophotometrically, in the same manner as described in the previous paper. Iron analysis of water was made by o-phenanthroline method. ${ }^{3}$

\section{RESULTS AND DISCUSSION}

1. Effect of Metal Ions on Riboflavin Production.

Sixteen kinds of metal ions were tested in concentrations of 10,100 and $500 \% \%$. Each of them was added as a soluble salt to the medium containing Ca-acetate (corresponding to $6 \%$ of acetic acid). Iron was tested separately in another experiment, because it has been known as a very important factor for some flavinogenic microorganisms. The results obtained after 5 days' culture are shown in Table I. Bismuth in $500 \% \%$, Li in $100 \%$ and $\mathrm{Mn}$ in $10 \%$ con-

3) L.G. Saywell and B.B. Cunningham, Ind. Eng, Chem, Anal. Ed., 9,67 (1937); W.B. Fortune and M.G. Mellon, ibid., 10, 60 (1938). 
Table I. EFfect of Metal Ions

\begin{tabular}{cccc} 
& \multicolumn{3}{c}{ Riboflavin, mg \% } \\
\cline { 2 - 3 } Metal & 10 & 100 & $500 \mathrm{r} \%$ \\
$\mathrm{Al}$ & 11.8 & 14.2 & 12.2 \\
$\mathrm{Ag}$ & 12.3 & 3.5 & 0 \\
$\mathrm{Ba}$ & 11.0 & 12.2 & 12.4 \\
$\mathrm{Bi}$ & 13.7 & 14.4 & 17.0 \\
$\mathrm{Cd}$ & 12.4 & 13.6 & 12.8 \\
$\mathrm{Co}$ & 11.6 & 12.0 & 13.2 \\
$\mathrm{Cu}$ & 11.1 & 4.3 & 0.9 \\
$\mathrm{Hg}$ & 12.6 & 11.8 & 0 \\
$\mathrm{Li}$ & 12.4 & 15.3 & 14.1 \\
$\mathrm{Mn}$ & 15.3 & 12.2 & 10.6 \\
$\mathrm{Ni}$ & 12.0 & 12.9 & 14.3 \\
$\mathrm{~Pb}$ & 12.0 & 12.2 & 12.0 \\
$\mathrm{Sb}$ & 12.5 & 12.9 & 12.1 \\
$\mathrm{Sn}$ & 12.8 & 12.4 & 12.6 \\
$\mathrm{U}$ & 12.4 & 12.8 & 12.3 \\
$\mathrm{Zn}$ & 12.1 & 12.6 & 12.8 \\
$\mathrm{None}$ & 12.6 & &
\end{tabular}

centrations, respectively, were somewhat effective in promoting riboflavin production. On the other hand, $\mathrm{Ag}, \mathrm{Cu}$ and $\mathrm{Hg}$ strongly inhibited its production when present in the medium in increasing concentrations. However, none of the other metals appreciably influenced its biosynthesis.

In this connection, riboflavin production by Eremothecium ashbyii is stimulated by $\mathrm{Zn}$;) that of Candida guilliermondii is also promoted with $\mathrm{Zn}^{5,6)}$ and $\mathrm{Co}^{73}$ In the case of Clostridium acetobutylicum, however, riboflavin production is extremely inhibited by the presence of small quantities of $\mathrm{Co}^{8,9)}$ and $\mathrm{Ni}^{9}{ }^{93}$

\section{Effect of Iron on Riboflavin Production.}

Ferrous sulfate was added in concentrations ranging from 0 to $100,000 \% \%$ as iron to the same medium as that previously used. The basal medium itself already contained $10 \% \%$ of iron,

4) H. Naganishi and R. Saruno, Vitamins (in Japanese), 2, 133 (1949).

5) F. Knüsel, Arch. Mikrobiol., 27, 219 (1957)

6) W.H. Schopfer and F. Knüisel, Schweiz. Z. allgem. Path. w. Bakt., 19, 659 (1956); Chem. Abstr., 51, 3732 (1957).

7) T.M. Enari, Ann. Acad. Sci. Fennicae Sec. A., Il, No. 90, \& (1958); Chem. Abstr., 53, 2361 (1959).

8) C.F. Artzberger, U.S. Patent, 2,326,425 (1943).

9) K. Inai, J. Agr. Chem. Soc. Japan, 29, 567 (1955).
Table II. EFfect of Various Concentrations of IRON

\begin{tabular}{|c|c|c|c|c|c|c|}
\hline \multirow{2}{*}{$\begin{array}{l}\text { Iron } \\
\text { ro\% }\end{array}$} & \multicolumn{5}{|c|}{ Rate of pigmentation } & \multirow{2}{*}{$\begin{array}{c}\text { Riboflavin, } \\
\text { mg } \% \\
\text { (5 days) }\end{array}$} \\
\hline & 1 & 2 & 3 & 4 & 5 days & \\
\hline 0 & \pm & H & H & HH & 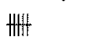 & 16.62 \\
\hline 50 & \pm & H & H & 册 & 册 & 12.34 \\
\hline 100 & \pm & H & H & 册 & $H$ & 8.22 \\
\hline 500 & \pm & H & $H$ & Ht & $H$ & 6.14 \\
\hline 1000 & \pm & + & H & H & 卅 & 2.99 \\
\hline 5000 & - & \pm & + & + & + & 0.16 \\
\hline 10000 & - & \pm & \pm & + & + & 0.13 \\
\hline 50000 & - & 一 & - & \pm & \pm & 0.06 \\
\hline 100000 & - & - & - & - & \pm & 0.06 \\
\hline
\end{tabular}

because no treatment was made for the removal of this metal from the tap water employed. The results obtained after a period of 5 days are shown in Table II. It may be observed that riboflavin production was sharply reduced with increasing concentrations of iron. However, it appeared that there were no great differences in

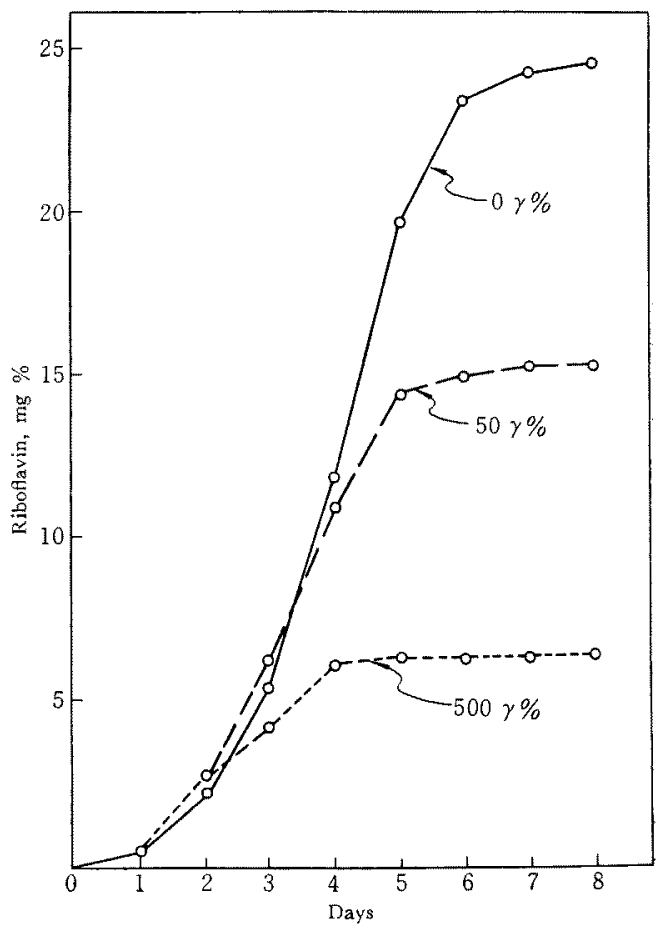

Fig. 1. Effect of Iron on the Rate of Ribollavin Production. 
respect to the rate of riboflavin production during the early stages of incubation, when using iron concentrations of 0 to $500 \% \%$.

The results of detailed experiments are summarized in Fig. 1. Some flavinogenic microorganisms are well-known to be strongly inhibited in respect to riboflavin production when iron is present in the media; for example, two genera, Clostridium and Candida, are quite sensitive to this metal. In the case of E. ashbyii, riboflavin production is not markedly affected by the presence of iron. A level as high as $0.04 \%$ of iron is reported to be inhibitory, ${ }^{4)}$ but $0.02 \%$ of FeSO $\mathrm{S}_{4} \cdot 7 \mathrm{H}_{2} \mathrm{O}$ is sometimes added to the medium for its production. ${ }^{10)}$ Yamasaki $^{11}$ reported that riboflavin was scarcely produced by $\mathrm{Cl}$. acetobutylicum when the level of $\mathrm{FeSO}_{4} \cdot 7 \mathrm{H}_{2} \mathrm{O}$ was $0.5 \mathrm{mg} \%(100 \gamma \%$ as $\mathrm{Fe})$ in the medium and no riboflavin was found in a $1 \mathrm{mg} \%$ concentration $(200 \% \%$ as $\mathrm{Fe})$. Leviton ${ }^{12)}$ showed that only ferrous iron was inhibitory, but Katagiri ${ }^{13)}$. Obata and Tomoeda, ${ }^{14)}$ and Imai ${ }^{15}$ stated that both ferrous and ferric irons were similarly antiflavinogenic. Tanner et $\mathrm{al}^{16}{ }^{16}$ indicated that the optimum concentration of iron was about $100 \% \%$ for this bacterium and this was 100 times greater than the optimum concentration for the Candida species. Van Lanen ${ }^{17)}$ also reported that 100 to $300 \gamma \%$ of iron was optimum.

Tanner et al. ${ }^{16)}$ observed that the addition of $10 \% \%$ of iron sharply reduced riboflavin synthesis by $C$. guilliermondii and $C$. flareri, and the highet yields were obtained in the concentrations of 0.5 to $1 \gamma \%$. Levine et al. ${ }^{182}$ obtained high yields of riboflavin by these strains when the iron content of the medium was held to a minimum 4 to $6 r \%$. However, a previous treatment for

10) B. Tabenkin, U.S. Potent, 2,493,274 (1950).

11) I. Xamasaki, Biochem. $Z$, 307, 431 (1941).

12) A. Leviton, J. Am. Chem. Soc, 68, 835 (1946).

13) H. Katagiri, Symposia on Enzyme Chemistry (in Japaneser, 6 , 3 (1951).

14) Y. Obata and M. Tomoeda, J. Agr. Chem. Soc, Japan, 27, 867 (1953).

15) K. Imai, ibtd, 29, 570 (1955).

16) F.W. Tanner, C. Vojnovick and J.M. Van Lanen, Science, 101, $180(1945)$.

17) J.M. Van Lanen and F.W. Tanner, Vilamins and Hormones, vi., Academic Press, New York (1948).

18) H. Levine, J.E. Oyaas, L. Wasserman, J.C. Hoogerheide and R.M. Stern, Ind. Eng. Chem., 41, 1665 (1949). removal of iron from the medium is sometimes necessary to get such low levels of this metal. These yeasts, therefore, appear to be unfavorable for use in the commercial production of this vitamin.

Ten $r \%$ of iron, which was extremely inhibitory to the synthesis of riboflavin by the abovenamed Candida species, was already contained in the medium without the addition of iron in this experiment. C. robusta was able to produce large amounts of riboflavin in this medium, so that any consideration for the removal of iron is not necessary. This fact, in addition to its high ability to synthesize riboflavin, suggests the possibility that C. robusta may be used for commercial purposes.

3. Necessity of $\mathrm{CaCO}_{3}$ for Riboflavin Production. 1) Physical effect of $\mathrm{CaCO}_{3}$. As reported in the previous paper, $\mathrm{CaCO}_{3}$ was essential for riboflavin production by $C$. robusta. Since considerable amounts of organic acids were produced in the sucrose medium containing $\mathrm{CaCO}_{3}$ during the early stages of incubation, $\mathrm{CaCO}_{3}$ seems to act as a neutralizing agent. On the other hand, the addition of $\mathrm{CaCO}_{3}$ was required even in Ca-acetate medium. Therefore, $\mathrm{CaCO}_{3}$ may,

Table III. EFfect on Riboflavin Production of THE RePlacement of $\mathrm{CaCO}_{3}$ By SOME Materials

$\begin{array}{ccc}\begin{array}{c}\text { Material } \\ (5 \%)\end{array} & \begin{array}{cc}\mathrm{CaCO}_{3} \\ \%\end{array} & \begin{array}{c}\text { Riboflavin } \\ \mathrm{mg} \%\end{array} \\ \text { Sand } & \begin{cases}0 & 0 \\ 0.5 & 0.08 \\ 1.0 & 0.15\end{cases} \\ \text { Quartz sand } & \begin{cases}0 & 0 \\ 0.5 & 0.18 \\ 1.0 & 0.42\end{cases} \\ \text { Diatomaceous earth } & \begin{cases}0 & 0 \\ 0.5 & 0 \\ 1.0 & 0\end{cases} \\ \text { Activated earth } & \begin{cases}0 & 0 \\ 0.5 & 0 \\ 1.0 & 0\end{cases} \\ \text { Activated alumina } & \begin{cases}0 & 0.53 \\ 0.5 & 1.77 \\ 1.0 & 2.74\end{cases} \\ \text { None } & \left\{\begin{array}{lll}0 & 0 \\ 0.5 & 0.28 \\ 1.0 & 0.52 \\ 5.0 & 5.72\end{array}\right.\end{array}$

19) R.A. Steinberg, J. Agr. Research, 51, 413 (1935). 
also, possess some physical advantage such as the absorption of inhibiting substance. In this connection, Steinberg ${ }^{19}$ reported that $\mathrm{CaCO}_{3}$ was very effective for the removal of metal ions, such as $\mathrm{Fe}, \mathrm{Zn}, \mathrm{Cu}$ and $\mathrm{Mn}$, from the medium. In order to examine the possible physical effect of $\mathrm{CaCO}_{3}$, several substitutive materials were added to the medium containing $3 \%$ of sucrose. The results obtained after 5 days' shaking culture are shown in Table III. It appears that $\mathrm{CaCO}_{3}$ has a certain physical effect, because activated alumina was somewhat effective in respect to riboflavin production in the medium containing no $\mathrm{CaCO}_{3}$.

2) Addition of activated alumina to acetate medium. Activated alumina was added in concentrations of 1 to $40 \%$ to the medium containing Ca-acetate (corresponding to $6 \%$ of acetic acid). The resulting data are shown in Table IV. High concentrations of activated alumina were as effective as $\mathrm{CaCO}_{3}$ on riboflavin production in the acetate medium.

Table IV. Effect of Activated Alumina on the Production of Riboflavin in Acetate MEDIUM

Activated
alumina
$\%$
1
3
5
7
10
13
16
20
30
40

Ribolavin
after 5 days
mg \%
0
0
0.03
0.08
0.36
0.42
1.91
20.92
22.00
19.29

3) Addition of small amounts of $\mathrm{CaCO}_{3}$ to acetate medium. In the Ca-acetate medium, a neutralizing agent did not appear to be needed for promoting acid production. It is, however, necessary to neutralize the broth when the optimum reaction for riboflavin synthesis by this yeast is approximately neutral, because the $\mathrm{pH}$ drops to some extent when the sulfate ions are liberated from $\left(\mathrm{NH}_{4}\right)_{2} \mathrm{SO}_{4}$ during fermentation even
Table V. Effect of Small Amounts of $\mathrm{CaCO}_{3}$ on Riboflavin Production

$\begin{array}{lc}\mathrm{CaCO}_{3} \% & \begin{array}{c}\text { Ribotlavin } \\ \mathrm{mg} \%\end{array} \\ 0 & 0 \\ 0.25 & 20.00 \\ 0.5 & 21.13 \\ 0.75 & 20.53 \\ 1.0 & 20.80 \\ 5.0 & 21.60\end{array}$

in the acetate medium. Aqueous suspensions of activated alumina are slightly alkaline, by the way. Hence, the alumina possesses some ability to neutralize the broth. If the above consideration is appropriate, much riboflavin must be produced in the acetate medium by the addition of small amounts of $\mathrm{CaCO}_{3}$ to neutralize the liberated sulfate ions. As $5 \%$ of $\mathrm{CaCO}_{3}$ has been used in the previous experiments, concentrations of 0.25 to $5 \%$ were tested in the Caacetate medium (containing 7\% acetic acid). The results obtained after 6 days' culture are summarized in Table V. As little as $0.25 \%$ of $\mathrm{CaCO}_{3}$ produced a yield of riboflavin similar to those obtained with higher concentrations. Based on these results, $\mathrm{CaCO}_{3}$ and activated alumina are considered to be useful, almost exclusively, as a neutralizing agent.

4) Riboflavin production without the addition of $\mathrm{CaCO}_{3}$. According to the above consideration, riboflavin should be produced without an addition of $\mathrm{CaCO}_{3}$ by using nitrogen sources which

\begin{tabular}{|c|c|c|c|c|}
\hline \\
\hline OF VARIOUS & $\begin{array}{l}\text { ITROGE } \\
\text { ADDI }\end{array}$ & $\begin{array}{l}\text { N SOUR } \\
\text { ION OF }\end{array}$ & $\begin{array}{l}\mathrm{ES} \text { USE } \\
\mathrm{CaCO}_{3}\end{array}$ & WITHOUT \\
\hline \multirow{2}{*}{$N$ source } & \multirow{2}{*}{$\begin{array}{l}\text { Ace- } \\
\text { tate }\end{array}$} & \multicolumn{2}{|c|}{$\mathrm{pH}$} & \multirow{2}{*}{$\begin{array}{l}\text { Riboflavin } \\
\text { after } 6 \text { days } \\
\text { mg } \%\end{array}$} \\
\hline & & Initial & Final & \\
\hline Urea & $\left\{\begin{array}{l}\mathrm{Ca}- \\
\mathrm{Na}-\end{array}\right.$ & $\begin{array}{l}6.4 \\
7.2\end{array}$ & $\begin{array}{l}7.0 \\
8.6\end{array}$ & $\begin{array}{l}4.55 \\
0\end{array}$ \\
\hline Alanine & $\left\{\begin{array}{l}\mathrm{Ca}- \\
\mathrm{Na}-\end{array}\right.$ & $\begin{array}{l}6.0 \\
6.6\end{array}$ & $\begin{array}{l}6.4 \\
8.6\end{array}$ & $\begin{array}{l}0 \\
0\end{array}$ \\
\hline$\left(\mathrm{NH}_{4}\right)_{2} \mathrm{CO}_{3} \cdot \mathrm{H}_{2} \mathrm{O}$ & $\left\{\begin{array}{l}\mathrm{Ca}- \\
\mathrm{Na}-\end{array}\right.$ & $\begin{array}{l}6.6 \\
6.8\end{array}$ & $\begin{array}{l}7.0 \\
8.0\end{array}$ & $\begin{array}{c}33.38 \\
0\end{array}$ \\
\hline$\left(\mathrm{NH}_{4}\right)_{2} \mathrm{SO}_{4}$ & $\left\{\begin{array}{l}\mathrm{Ca}- \\
\mathrm{Na}-\end{array}\right.$ & $\begin{array}{l}6.0 \\
6.6\end{array}$ & $\begin{array}{l}6.4 \\
8.2\end{array}$ & $\begin{array}{l}0 \\
0\end{array}$ \\
\hline 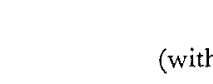 & Ca- & $\begin{array}{c}6.5 \\
\left.\mathrm{CO}_{3}\right)\end{array}$ & 7.0 & 21.63 \\
\hline
\end{tabular}


do not liberate any strong acid radical during the fermentation. Urea, alanine and $\left(\mathrm{NH}_{4}\right)_{2} \mathrm{CO}_{3}$. $\mathrm{H}_{2} \mathrm{O}$ were then supplied in a concentration corresponding to a nitrogen level of $0.3 \%\left(\mathrm{NH}_{4}\right)_{2} \mathrm{SO}_{4}$ in $\mathrm{Ca}$ - or $\mathrm{Na}$-acetate media (as 7\% acetic acid). As shown in Table VI, riboflavin was produced in the absence of $\mathrm{CaCO}_{3}$ in the Ca-acetate medium containing urea, or $\left(\mathrm{NH}_{4}\right)_{2} \mathrm{CO}_{3} \cdot \mathrm{H}_{2} \mathrm{O}$. Actually, the latter gave a greater yield of riboflavin than $\left(\mathrm{NH}_{4}\right)_{2} \mathrm{SO}_{4}$ with $\mathrm{CaCO}_{3}$, although small amounts of $\mathrm{CaCO}_{3}$ were present in the medium after sterilization, as a result of the combination of Ca-acetate and $\left(\mathrm{NH}_{4}\right)_{2} \mathrm{CO}_{3}$. On the other hand, the final reaction was $\mathrm{pH} 7.0$ whenever riboflavin was found in the broth.

\section{Optimum $\mathrm{pH}$ for Riboflavin Production.}

The different $\mathrm{pH}$ values were obtained by adjustment of the media with $\mathrm{HCl}$ or $\mathrm{KOH}$ before sterilization. The results obtained with the medium containing Ca-acetate (corresponding to $7 \%$ acetic acid) and $0.25 \%$ urea in shake tubes after 7 days are shown in Table VII. A favorable $\mathrm{pH}$ for the riboflavin production by $C$.

\begin{tabular}{|c|c|c|}
\hline TABLE VII. & $\begin{array}{l}\text { EFFECT OF } \mathrm{pH} \text { ON } \\
\text { PRODUCTION }\end{array}$ & RIBOFLAVIN \\
\hline $\begin{array}{l}\text { Initial pH } \\
\quad \text { after } \\
\text { sterilization }\end{array}$ & Final $\mathrm{pH}$ & $\begin{array}{c}\text { Ribollavin } \\
\text { after } 7 \text { days } \\
\text { mg } \%\end{array}$ \\
\hline 6.0 & 6.2 & 0 \\
\hline 6.1 & 6.3 & 0 \\
\hline 6.2 & 6.6 & 0.48 \\
\hline 6.3 & 7.0 & 3.70 \\
\hline 6.4 & 7.0 & 12.00 \\
\hline 6.6 & 7.0 & 13.45 \\
\hline 6.8 & 7.0 & 13.60 \\
\hline 7.0 & 7.0 & 14.35 \\
\hline 7.3 & 7.0 & 13.75 \\
\hline 6.6 & 7.0 & 14.40 \\
\hline
\end{tabular}

(with $5 \% \mathrm{CaCO}_{3}$ ) robusta was found to be about 7.0 ; when it was 6.1 , or below, the vitamin was not produced. Based on these results, it is believed that the effects of $\mathrm{CaCO}_{3}$ and activated alumina on riboflavin biosynthesis are due to the neutralizing action, not only in sucrose medium but also in acetate medium.

The optimum $\mathrm{pH}$ ranges for ribohavin production by some flavinogenic microbes are as follows: $E$. ashbyii, $\mathrm{pH} 5.5$ to $6.44^{10,20,21)}$ A. gossypii, $\mathrm{pH} 6.0$ to $7.0{ }^{22)}$ C. guilliermondii and C. flareri, pH 5.0 or below; ${ }^{16,18}$ and a flavinproducing mutant of Saccharomyces cerevisiae, $\mathrm{pH} 5.0 .^{23}$ In the case of Cl. acetobutylicum, $\mathrm{CaCO}_{3}$ is usually added, but a pH 6.2 is sometimes used in the medium without the addition of $\mathrm{CaCO}_{3}{ }^{24)}$

It thus appears that above organisms prefer relatively low $\mathrm{pH}$ for riboflavin production. Accordingly, C. robusta is somewhat different from these organisms with regard to the optimum pH.

Acknowledgement. The author is indebted to Prof. Yuji Sasaki of this laboratory, Hokkaido University, for his valuable suggestion and encouragement throughout the work. $\mathrm{He}$ is also grateful to Dr. Cecil G. Dumn and Dr. Gerald Silverman, Department of Nutrition and Food Science, Massachusetts Institute of Technology, for their kindness in revising the manuscritp.

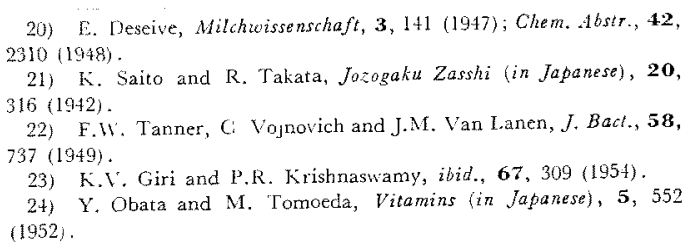

